\title{
SOME RENAISSANCE SCHOOLBOOKS IN THE OSBORIE COLLECTION
}

\author{
by \\ GERMAINE WARKENTIN
}

A small group of titles in the Toronto Public Library's splendid Osbome Collection of early childrens' books is from the period before 1700. The smallness of

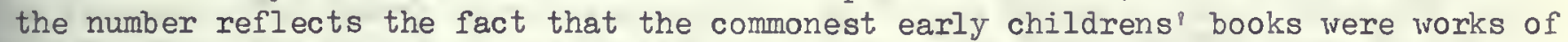
instruction, and they simply wore out after decades of use. But it results also from the collecting habits of Edgar Osborne, whose interest in imaginative literature for children led him to collect only a few representative examples of the early schoolbook. The library has, however, added a number of sixteenth century titles since the collection was housed there, and more are purchased from time to time.

The present Renaissance holdings of the collection (53 titles before 1700 out of 8000 accessions including serials) represent many kinds of early young peoples" books. They range from a black-letter grammar (Strasbourg, 1505), through the popular tale Valentine and Orson (in what is believed to be a rare edition of 1688), to one of the earliest of "modern" children's books, the Histoire ou Contes du temps passé of Charles Perrault (Paris, 1697). There are tivo editions of the influential Horapollo (recorded in R\&R's "Census of Emblem Books in Toronto," II (3) 1-7 and III (1) 2-13), three mathematical works, a number of titles typical of the formal grammar school curriculum, a recusant catechism, a superb broadsheet $A B C$ which we reproduce on page 6 , and many books to instruct youth in devout and proper behaviour. These last fall into the category of courtesy literature, and will perhaps be treated in another issue of R\&R. The books to which I have limited myself in the list that follows are those that a young person might have met during his formal education, whether that of apprentice or gentleman.

Though there are one or tivo rareties, several items not in STC or Wing, and some very beautiful books that witness to the stature of the Osborne collection, the only titles that can be approached as a group are nine interesting items of Aesopiana. Several of the six continental editions of Aesop employ the same pool of woodcuts; sometimes, however, cuts have been redraw, as we can see in the several versions of "senex et mors" on page 4. Except for the smallest books, the Aesops follow the miscellaneous format of such volumes; most contain some selection of Aesopian fables, with Latin renderings by Avienus and perhaps Valla and other authors, the Vita of Planudes, and most frequently the mock-epic Batrachomyomachia (Battle of the Frogs and Mice) once ascribed to Homer.

A seventeenth-century cause célèbre is reflected in the elegant Aesop printed at Oxford in 1698, which contains 158 fables in Greek, ten in Hebrew, and eight in Arabic (in each case with parallel Latin) and another sixty in Latin alone. The text of Aesop was an issue in the battle during this period over the superiority of "ancients" to "moderns." The preface of the Oxford Aesop (illustrated on page 4 ) takes the side of the "ancients" in loftily patronizing the scholarship of the "moderns'" Richard Bentley (who had revealed that the Fables, though ancient, were spurious), but on a later page the editor, Anthony Alsop nervously displays the manuscript and printed sources from which his fables vere chosen. The volume is dedicated, in the high vein of the Dunciad, to James Scudamore, Viscount Scudamore of Slego, with verses by Alsop beginning, 
Augusta pubes: ô per:antiquae Domus

Spes summa: surgens Scudamoreorum decus!

For his services to poetry and scholarship, Alsop was rewarded with a mauling in the very' passage of Duncaid IV in which Pope savages Bentley。

Some titles that had to be omitted from my list of schoolbooks may nevertheless interest readers of R\&R. One in particular is The Images of the Old Testament. lately expressed, set forthe in Ynglisshe and Frenche, with a playne and brief exposition, (Lyon, Jean Frellon, 1549). This is a beautifully printed edition of Historiarum veteris Instrumenti icones, first published in Iyon in 1538 by M。 \& G。 Trechsel. The fine engravings are after drawings wholly or in part by Hans Holbein the Younger. The French verses are probably by Gilles Corrozet, but I have not been able to trace the author of the English versions. John Dunton's The Young Student?s Library, "by the Athenian Society,"(London, 1692, Wing D 2635) cannot have been intended for schools. It is really a species of seventeenth-century Reader:s Digest, amiably mingling excerpts from writings on philosophy, theology, voyages, natural science, etc. Three books that fall beyond my terminal date of 1700 are: a pair of "Lily" grammars bound with Lily's Rules Construed, of the 17th century schoolmaster William Haines (London, William Norton, 1704-5); an edition of Cato prepared by another 17th century educator, Charles Hoole (London, R. Harbin for the Company of Stationers, 1728): and 'thectrelfth English edition of Comenius' Orbis Sensualium Pictus (London, S. Leacroft, 1777).

Some of the books listed here have not yet been catalogued in the Osbome Collection. Many more have been purchased since the first published catalogue listed a mere 3000 volumes in 1958. Miss Judith St. John, Librarian in charge of the collection, who gave me valued assistance in preparing the list of schoolbooks, says that a new printed catalogue is now being contemplated.

(N.B. The listing attempts to reproduce the wording of titles faithfully, but capitalization and punctuation have frequently been regularized。)

\section{Some Renaissance Schoolbooks in the Osborme Collection:}

\section{[A.B.C.] Tabulae abcdariae pueriles.}

[Leipzig, Valentin Babst, ca。1544]

[Illustrated on page 6. Records of the Osbome Collection report, "The printer has been identified by typographical comparisons。 This is probably one of the oldest instruction sheets to have survived.... A few specimens were discovered about 1925 in a record office in Germany."]

- [The Osborme Collection possesses an English Bible of 1606 in the original binding. Pasted inside the front and back covers are two quarters of an illustrated English A.B.C., date unknom, apparently printed at York。]

[AESOPOS] Aesopi fabulatoris clarissimi, tres \& triginta fabulae ... ab Laurentio Valla e graeco in latinum sermonem conversae.

Paris, Simon de Colines, 1521

19 leaves。

[Bookplate: ex libris: Jos. Neve.]

- Fabellae Aliquot Aesopicae, in usum puerorum selectae。

Antiverp, Christopher Plantin, 1566。Ills。

66 ppo +6 unnumbered。 


\section{Præfatio.}

CIO extitife nonnullos qui acerrimè contenderent, 1 has quse vulgò circumferuntur EEfopi Fabulas, ab Efopo illo Fabularum Philofopho nonfuiffe confcriptas : quod nuperrimè fecilfe audio Ricliardum quendam Bentleium Virum in volvendis Lexicis fat is diligentem. Mihi vero non tam Autoris nomen quàm Libri materiam छิ utilitatem expendenti, exhivere fufficit Fabellas $\sqrt{i}$ non ab EETopo, ad illius faltem mentem \& normam cumpofitas, quas proinde सEfopicas infcripfi. Earum quas nunc edo Quis fuer it Autor, inquirendum iis relinquo quibus pluris eft Scriptorem fcire, quàm ex Scripto proficerc.

Neque vero de Fabulis dubitari mirum eft cum 俅opus Autor fit in incerto. Phryx an Sanius an Thrax fuerit per Scriptores Clajficos ambigere licet: quid Planudes Monachus ad fui fimiles foripferit, non moramur. De Parentibus Ejus minus conftat quam de Autorc Fabularum; Hos nè Planudes quidem per otii fui diligentiam invenit. Servizße $\mathbb{E}$ Copum, credimus Herodoto, cui credzdit Plınius; fuiffe etiann Rhodopidis meretricis conferoum; Xantho an Iadinoni fervierit an utrigue, fueritne Xanthus ille Pbilofophus, Gै cujus Secta, difceptandum aliv relinquimus: horum enim siqua fit celebritas, non eft illa virtutibus ipforum propriis, fed fervi fui fame tribuenda. Si ut plerif-

a 4

que

Opening of the Preface to the Aesop edited by Anthony Alsop and published at Oxford by John Croke in 1698.
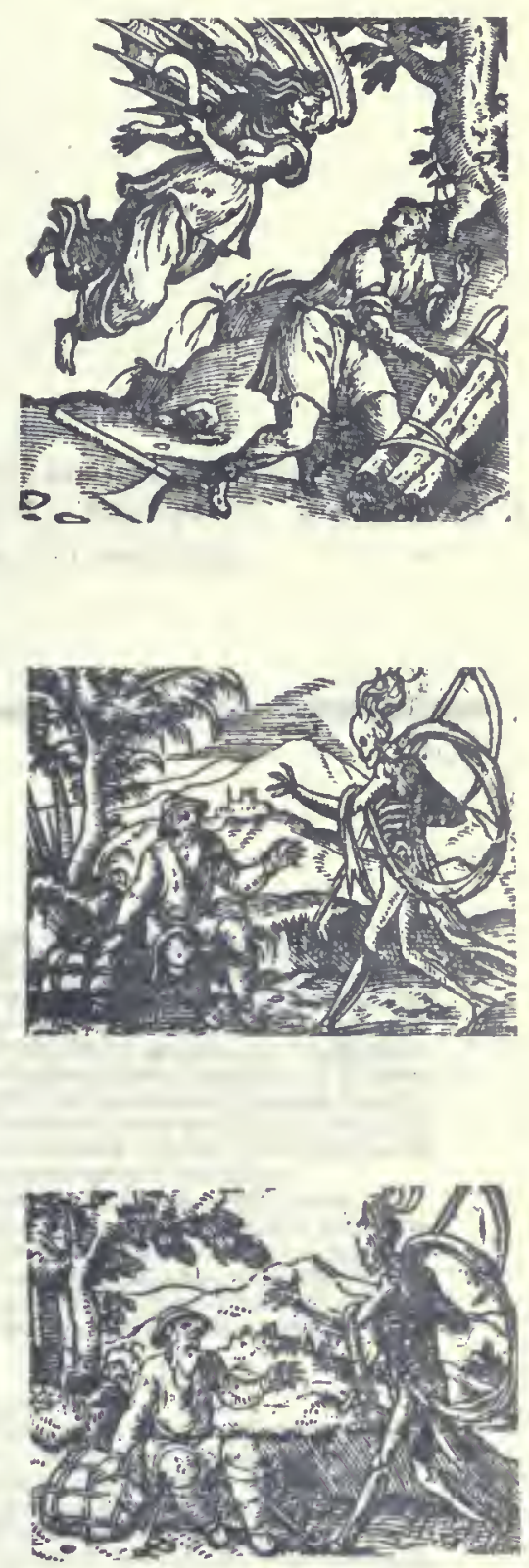

SENEX ET MORS

Woodcuts from four editions of the fables of Aesop.

1) Antwerp, Plantin, 1566

2) Lyon, Jullieron, 1614

3) Lyon, Tournes, 1632

4) Amsterdam, Ravestyn, 1672

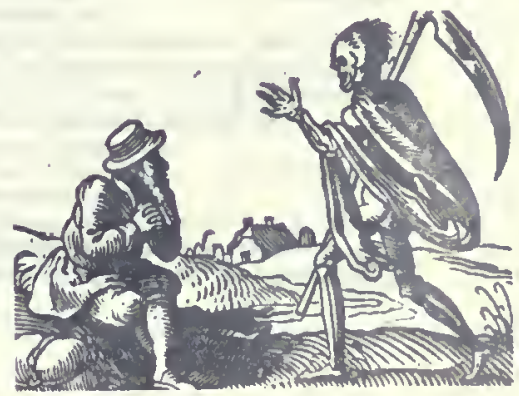

Photographs courtesy of the Toronto Public Library 


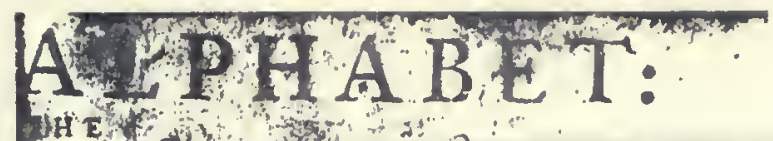

$\operatorname{lin}^{2} \mathbf{A}, \mathbf{A}, \mathbf{B}, \mathrm{C}$

Nertude and efchem vice, very necentary

thole solio defite inftructions.
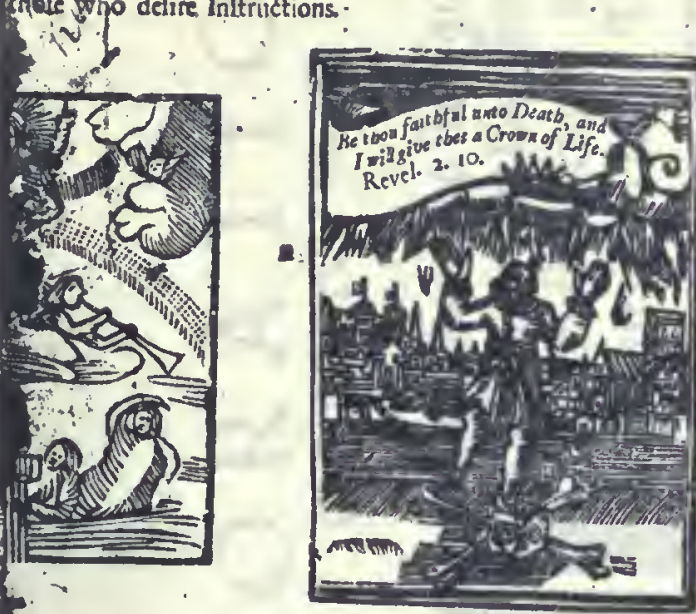

An undated English $A B C$ broadsheet, printed at York. Pasted in a Bible of 1606 in the Osborne Collection.

ou lincicale,

dis your Srore, arc put is place the porr. times truth,
diverist $;$;

Supream $j$ ton,

\section{है}

10 bliciun is lle grmar.

wanes Supriy.

re your Eres, Ints:

Stgevere bistis icep Holy thin

A sample page from the Compendium octo partium orationem published at Strasbourg by Matthias Hupfuf in 1505.

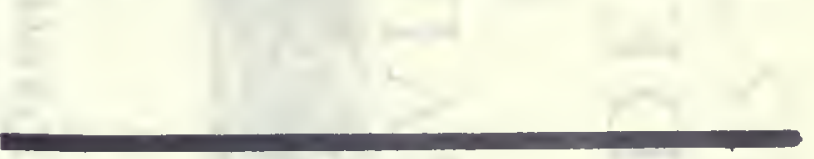

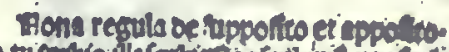

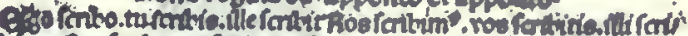

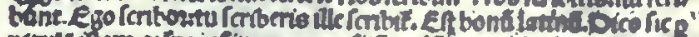

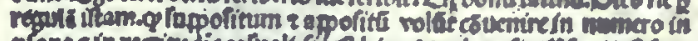

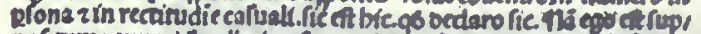

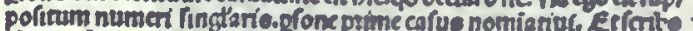
tat aporitum.ciufde numen.tivide pesfone vertit of

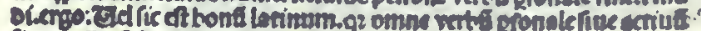

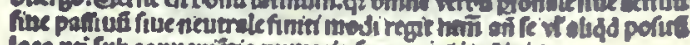
loco nti fub conuerretria numer plone a riectiond inis.

Recima regula oe sccoliatino stre infinírium.

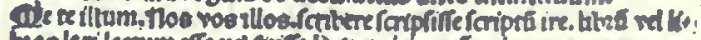
b200 legi lecrum efie vel farife lectum in

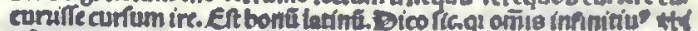

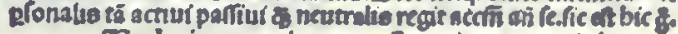

Endecima regule oe contrucrione vocatiof.

partrefalue

- Diffirale Entomum lattinum.

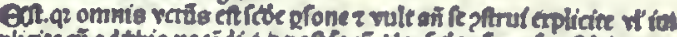

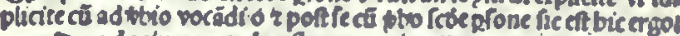
Ouodedma regula eft oc nominariuo o partepolt

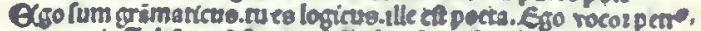
cu rocaris Jobines. Ine rocal Ecrbardue. Egefto erect. Lu vi

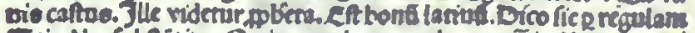

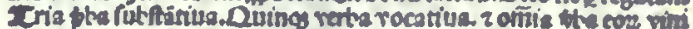

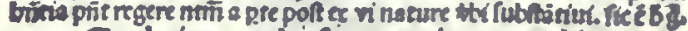
Credecina regula ef notatu olgne oe verbto. IDonarbus famocinat 2 predicar populb.

"Donot axbiket z oacur oocto viro

entronotathom Canue viuiz zlaterar oominofuo.

Dico fieper piman regulam suream que talis th. Omne viture

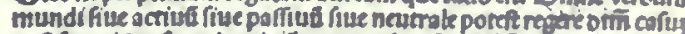

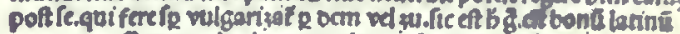
Duertadecima regula ctelt notan olgms

ID ugifter legit ousa bozae vel ouabo boris.

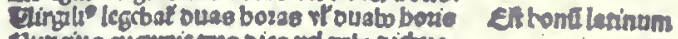
Numcius cicturit tree oles vel mbo biduse

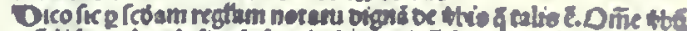

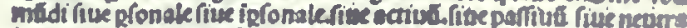

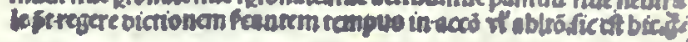

Photographs courtesy of the Toronto Public Library 


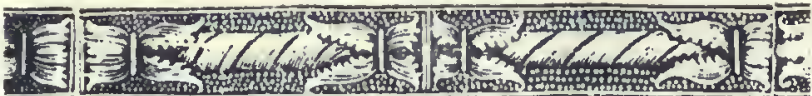

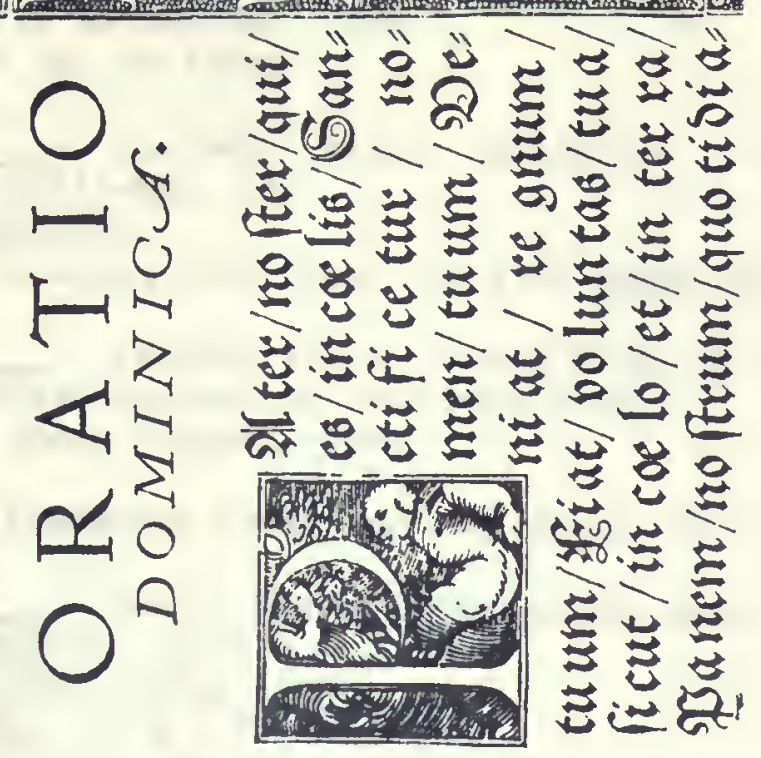

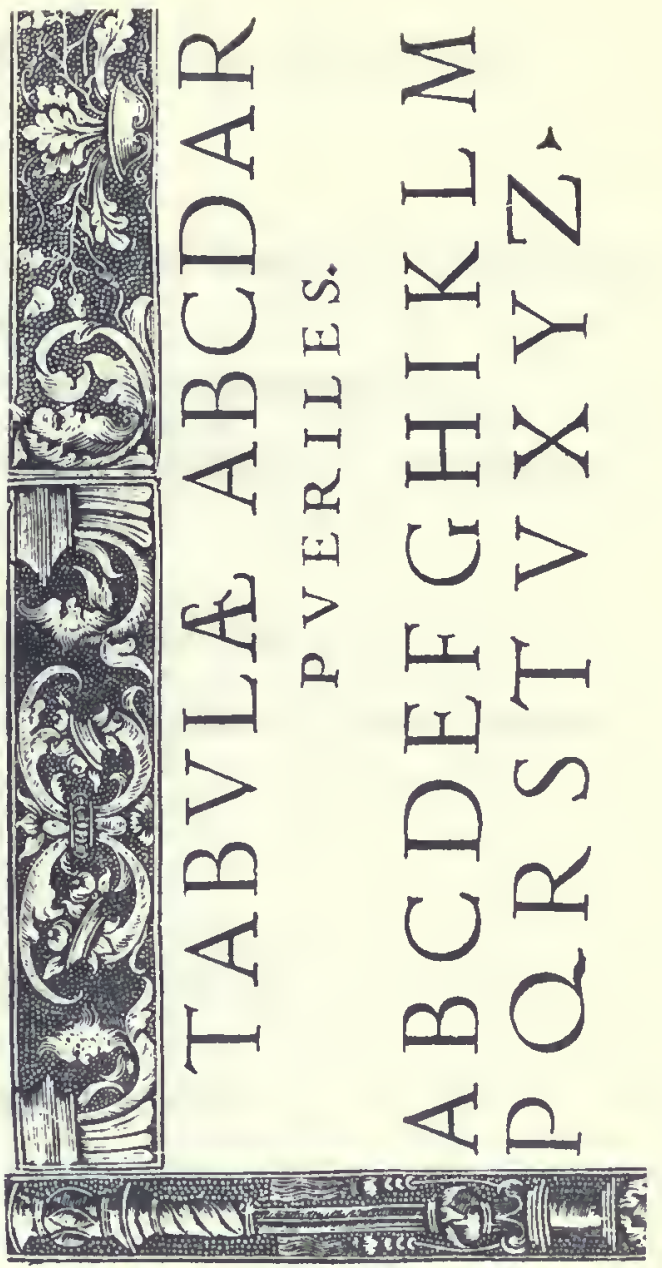

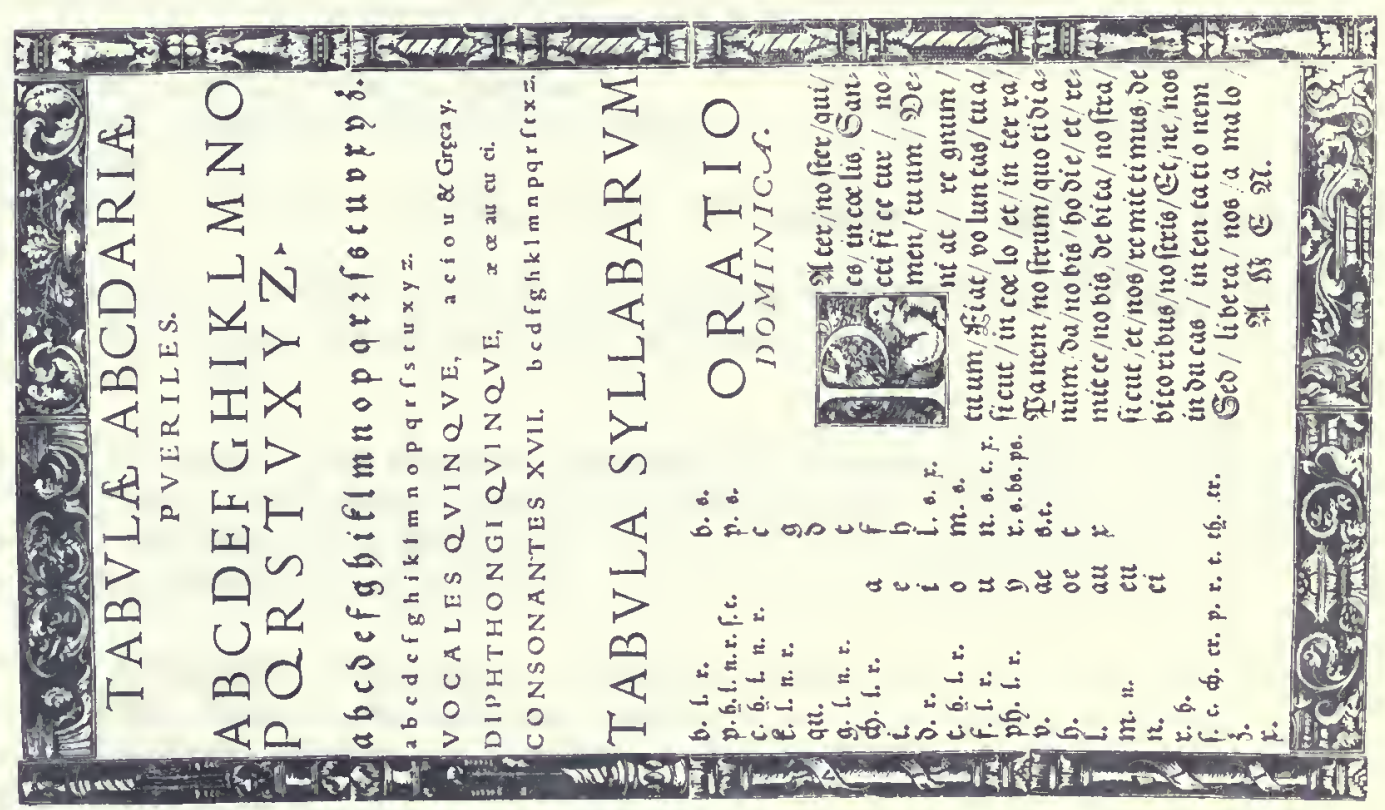


species ad vivum adumbrantes.

Lyon, Jean II de Tournes, 1582

$410 \mathrm{pp}$. $+6 \mathrm{pp}$. of Index

- [Ae]sopi Phrygis fa[bu]lae, elegantis [simis] iconibus illustratae. ....

Lyon, Jean Jullieron, 1614

$427 \mathrm{pp},+$ Indices.

[Another edition of the 1582 Aesop above. T.p. much tattered。]

D.D. Hollandiae ordinum in usum Scholarum,

Amsterdam, Joan. Jansson, 1653.

$160 \mathrm{pp}$.

[Prefatory Greek verse by Daniel Heinsius. Contemp。 sig。 on t.p.]

- Aesopi Phrygis Fabulae Jam recenter ex collatione optimorum exemp-

larium emendatius excusae...

Cambridge, John Field, 1662.

xvi + $174 \mathrm{pp}$. Wing A 717

[ No illustrations. Contemp. sig. on $\left.t_{\circ} p_{\bullet}\right]$

- Fabulae Aesopi Graece \& Latine, nunc denuo selectae o.

Amsterdam, Johannes Ravestyn, 1672.

$160 \mathrm{pp}$. + ills.

[Appears to be another edition of the 1653 Aesop above.]

- Fables of Aesop and other eminent mythologists: with morals and reflexions, by Sir Rogert L'Estrange, Kt. London, printed for $R$. Sare et al., 1694. $\mathrm{xii}+476$ Wing A 707

[One volume of the second edition of L'Estrange's heavily moralized English version of Aesop. Sign. "I.L.Philips", on t.p.

- Fabularum Aesopicarum delectus.

Oxford, at the Sheldonian Theatre, John Croke, 1698.

128 pp. + Indices。 Wing A 729

[Edited by Anthony Alsop. Contemp. sig. "F. Bagshaw". Label: "Arbury Library."]

[ALVAREZ, MANOEL] Emmanuelis Alvari e Societate Iesu de Institutione Grammatica Pro Illyricis accomodata a Patribus eiusdem societatis Libri Tres.

Rome, Franciscus Caballus, 1637

$416 \mathrm{pp}$.

[One of approximately four hundred editions of this work by the eminent

Jesuit grammarian, first published in Lisbon in 1572. Several indications of provenance, including inscription on t.p. "Bibliotheca Colbertines" and stamp "Bibliotheca Heberiana."]

[COMENIUS, J.A.] Janua Linguarum Trilinguis, sive, Johannis-Amos Comenii Janua

Linguarum Novissime ab ipso Authore Recognita, Aucta,

Emendata: Adjunctis metaphrasi Graeca et Anglicana versione oo.

London, Roger Daniel, 1662。

$\mathrm{xvi}+274+$ Index, with 16 numbered drawings. Wing 05518 
(Another edition.)

London, J. Redmayne and J.Williams, 1670

xii $+274+$ Index, with drawings here interspersed in text. Wing C5519

Compendium octo partium orationem.

[Strasbourg, Matthias Hupfuf, 1505 (Colophon)]

66 leaves.

[Black letter. A grammatical treatise in five parts. The examples used seem to be primarily from the schoolroom setting. Part IV contains rules for translating from Latin to German, Part $V$ consists of precepts on elegant writing abstracted from Valla. "Ouvrage souvent réimpr。" (Graesse). The earliest dated edition I have been able to trace is Amerbach, Basle, 1489. This edition not in Schmidt, Répertoire, or in Ritter, Histoire. Possibly very rare.]

[FAERNO, GABRIELLO] Centum fabulae ex antiquis auctoribus delectae et a Gabriele Faerno Cremonensi carminibus explicata. Leyden, House of Plantin, printed by Christopher Raphelengien, 1600.

$173 \mathrm{pp}$. Many woodcuts.

[Each fable is set forth with a picture, a verse of varying length, and a moral. There is dedication to Cardinal Charles Borromeo.]

Gradus ad Parnassum; sive, novus synonymorum, epithetorum, phrasium poeticarum, ac versuum thesaurus, .... An uno e Societate Jesu. Editio Novissima. London, Benjamin Took and Thomas Cockerill, 1694.

$768 \mathrm{pp}$.

[Not in Wing. Sig. on t.p. The confused history of this very popular phrasebook can be surveyed in Sommervogel, Bib. Com. Jésus, I, 164-6, and II, 1091-6. This edition is after the verion of Paul Aler, S.J., who was active in Jesuit literary and theatrical affairs about this time。]

[GODWIN, THOMAS] Romanae Historiae anthologia recognita et aucta. An English Exposition of the Roman Antiquities ... for the use of Abingdon School. London, Printed by R.W. for Peter Parker, 1661. $v i+240 \mathrm{pp}+$ Index. Wing G 990。

[Prefatory epistle by Godwyn to Dr. John Young, Dean of Winchester. STC records nine editions of this popular handbook from 1614, and there are 16 more in Wing, the last in 1695.]

[JUVENAL AND PERSIUS] D。 Junii Juvenalis Satyrae in usum Scholae Westmonasteriensis。 London, John Redmayne, 1677.

pp. 122 .

[Not in Wing. This is the only early copy in the Osborne Collection of a standard author of the classical curriculum. Pencilled notation "no other copy known." Bookplate of William B. Heberden, Elmfield, Exeter.]

[LILY, WILLIAM] A Short Introduction of Grammar generally to be used ...

Oxford, at the Sheldonian Theatre, 1675.

pp. unnumbered. Wing L 2294 .

bound with:

Brevissima Institutio seu ratio Grammatices cognoscendae o. .

Oxford, at the Sheldonian Theatre, 1675.

$335 \mathrm{pp}$. Not in Wing.

[The earliest set in the Osbome Collection of the famed 16 th century grammars known simply as "Lily."] 
[OCLAND, CHRISTOPHER] Anglorum Praelia ab anno Domini 1327 anno nimirum primo inclytissimi Principis Eduardi eius nominis tertij, usque ad annum domini 1558. Carmine summatim perstricta. London, R. Newbery, assigned by Henry Bynneman, 1582. Angl. Prael and Eliz. unnumbered, Kettus 97 pp. STC 18773.

[Includes Ocland's Elizabetha, and Neville's Kettus, sive de furoribus Norfolciensium Ketto duce. On April 21, 1582, the Privy Council ordained that Anglorum Praelia, first published in 1580, replace the lascivious heathen poets fór üseein schools - T.W.Baldwin (Shakspere's Small Latine, I, $111-2$ ) doubts that the order remained long in force. The order is printed on the t.p. of this edition. STC lists four editions 1580-82.]

[PARDIESt I.G.] J.J. Elementa geometriae ... per P. Ignat. Gaston Pardies S.J. Gallico Idiomate conscripta, nunc vero post tertiam editionem in usum studiosae juventutis loftinitate donata.

Jena, Tobia Ohfling, 1684

24 leaves $168 \mathrm{pp}$. + Index.

[Pardies' Elemens de Geometrie was first published at Paris in 1671. This

Latin translation is by J.A.Schmidt, professor of theology at Helmstad.

Prefatory epistle to Nicholas Christopher Lynckerus.]

[PATER, JOHN] Artificial versifying, or the school-boy's recreation. A new way to make Latin verses whereby anyone of ordinary capacity, that only knows the A.B.C. and can count 9 (though he understands not ione word of Latin, or what a verse means) may be plainly taught, (and in as little time as this is reading over, ) how to make hundreds of hexameter verses, which shall be true Latin, true verse, and good sense. London, printed for John Sims, 1677.

ii $+20 \mathrm{pp}$.

[A Mechanick approach, with tables. Not in Wing, but the 1958 Osborne catalogue says that a third edition, of 1685, has been recorded.]

[RECORDE, ROBERT] The Ground of Artes: teaching the perfect worke and practise of Arithmeticke ... Made by M. Robert Record, D. in Physiche ... London, Henry Middleton for John Harrison, 1586.

$560 \mathrm{pp}$.

[Recorde's famous arithmetic was first printed in 1542. No 1586 edition is listed in STC. Dr. John Dee worked on the augmentations for revised editions of this work, and a verse by him appears at the end, where there is also a plug for the school run by John Mellis of Southwark, who prepared additional tables. Black.letter.]

- The Ground.of Arts teaching the perfect worke and practise of Arithmeticke ... made by Mr. Robert Record Dr. in Physick, afterward augmented by Mr. Iohn Dee ... and since enlarged by Iohn Mellis ... and now diligently perused by Robert Hartwell, Philomathemat ... London, Thos:. Harper for John Harrison, 1631. xxvi + $622 \mathrm{pp}$.

[A later edition of this much revised work, now with Hartwell's address cannily introduced at the end. STC lists an edition of 1632 , entered 29 June, 1630 (STC 20809).] 
[ROBIISON, HUGII] Scholae Wintoniensis phrases Latinae ... The Latine Phrases of Winchester School ... by H. Robinson, D.D. ... Published for the common use and benefit of the Grammar schools. London, printed for A. Moseley, to be sold by S. Speed, 1661. About 440 pages. Third edition. Wing R 1683.

[Heavily inscribed by boyish hands on the endpapers and prelims. The pages at beginning and end are disordered, suggesting the copy has been badly rebound. Wing lists ten editions from a "second" in 1658 to 1685.]

[SHIRLEY, JAMES] Via ad Latinam Linguam complanata. The Way made plain to the Latine Tongue. The Rules composed in English and Latine Verse: For the greater Delight and Benefit of Leamers. By James Shirley. London, printed by R.W. for John Stephenson, 1649. $125 \mathrm{pp}$. Wing $\mathrm{S} 3492$.

[A product of the famed playwright's original career of schoolmaster, which he resumed after the suppression of the theatres in 1642. Dedicated fulsomely to William Herbert, son of Rt. Hon. Philip, Lord Herbert, with cunning reminders of his Pembroke and Sidney connections. Prefatory verses by seven literary friends. No other editions in Wing. Sig. "Richard Bromes Booke."]

[TERENTIUS AFER, PUBLIUS] [[Flouros for latine speaking. London, Thomas Berthelet, 1560.]

203 leaves. STC 23901.

[This is an edition of the compendium made by Nicholas Udall in 1533 from the similar collection put together by Cornelius Graphius in 1530. T.p. of this copy is missing; almanac material bound in at beginning and end. Annot. in several schoolboy hands, including the ancient verse "Hic liber est meus ..." Bookplace of Francis, Duke of Bedford.]

[VAUX, LAURENCE] A catechisme or Christian doctrine necessarie for children and ignorante people ...

[Antwerp?] 1590.

Pages unnumbered. STC $24627^{a}$

[First published in Louvain, 1567]. The appended A brief fourme of confession first appeared in 1576 and the two parts were brought together in 1583. Vaux wrote this work (which became very well known) for the children of refugee English Catholics to whomche was once schoolmaster at Louvain. He died in an English prison in 1585. This copy is marked "Lincoln Cathedral Library," and appears to be the copy listed in STC which has migrated to Toronto.]

[VIVES, JUAN LUIS] Ioannis Lodovici Vivis Valentini, Introductio ad sapientiam, Satellitium sive Symbola: Epistolae duae de ratione studii puerilis ... [Antwerp,i(Antonius) Dumaeus, 1542 (Colophon)]

Pages unnumbered.

[A popular work for the introductory years of the grammar-school curriculum. Annot. on t.p. Bookplate, "Robert Wilmot."]

[WINGATE, EDMUND] Mr. Wingate's Arithmetick, containing a plain and familiar method, for attaining the knowledge and practice of common arithmetick.. [revised] by John Kersey。 London, printed by S.R. for R.S., to be sold by J. Williams, 1678.

$\mathrm{xii}+544 \mathrm{pp}$. Seventh edition. Wing W 3001 .

[Dedicatory epistle to Thomas, Earl of Arundel and Surrye. Contemp. signature "Mar. Gibbin" on t.p.] 